\title{
Investors decisions in Indian Stock Market - Effect of Herd Behavior
}

\author{
Nitin Saxena, Ankur Ahuja \\ Assistant Professor, \\ Institute of Technology \& Science, Ghaziabad, Uttar Pradesh, India
}

\begin{abstract}
:
Behavioral finance proposes that cognitive traits of investors impact their investment decisions which are not always rational, in contradiction to traditional finance. These cognitive traits of stock investors are influenced by their demographical profile and the financial information that they receive from various sources which in turn influences their stock investment decisions. Investors with similar demographic profile tend to follow a similar pattern with regard to their investment behavior biases. The main objective of this study is to analyze the impact of Indian stock investors' demographics and various sources of financial information on their cognitive biases. Various behavioral biases like herding, loss aversion, regret aversion, market information; mental accounting, price change, and price anchoring were studied but herding behavior has been taken into consideration for analysis in this study. A questionnaire was floated by using quota sampling. Stata software was used for analysis, by using ordered logistic regression on the conceived model. Gender, age, marital status and word of mouth are found to have significant impact on the herding behavior of stock investors
\end{abstract}

Keywords: Behavioral Finance, Cognitive Biases, Herding, Demographic Variables

\section{INTRODUCTION}

Behavioral finance has been successful in explaining the anomalies in the financial markets that traditional finance was unable to. Behavioral finance contradicts the assumption of rational investors in the financial markets as it believes that the theories of traditional finance fails to integrate in its propositions the crucial component of the investors being human beings who are subjected to the human element of making errors, of emotions, of the struggle for survival, of the need for security, and of the inbuilt mechanism to stay away from anything risky. These aspects are not taken into consideration in traditional finance and were even considered to be irrelevant. This is where behavioral finance intervenes and proposes its theory by integrating the impact of cognition, which is a permanent part of being human.

The existing foundations of financial theories of market efficiency and asset pricing are based on the premise of rational and utility maximizing investors. However, researchers across the globe have been fervent to investigate a new dimension to investor behavior and psychology. The classical finance theories ignore that market participants make errors and are guided by behavioral patterns in making investment choices and decisions. This leads to market anomalies and fluctuations. The modern financial theory has placed people and their psychology in the center of the debates. Such irrational human behavior has been the reason of global financial market overvaluations and eventual crises across time and its relevance has lead to the emergence of behavioral finance. One such irrational pattern as observed is herding behavior (Lakonishok et al., 1992; Christie and Huang, 1995) which involves mimicking the actions of other investors, which constitute the market consensus (Bikhchandani and Sharma, 2000). Banerjee (1992) defines herding as "everyone doing what everyone else is doing, even 
when their private information suggests doing something quite different." As per Hwang and Salmon (2004) "herding arises when investors decide to imitate the observed decisions of others or movements in the market rather than follow their own beliefs and information.'Hirshleifer and Teoh (2003) also define herding asany behavior similarity or dissimilarity brought about by the direct or indirect interaction of individuals. Herding can be classified as spurious Vs intentional (Bikhchandani and Sharma, 2000). Spurious herding is type of pseudo herding pattern where an investor takes similar decisions as others due to the same information and data possessed by them (Hirshleifer et al., 1994). Intentional herding is the conscious herd behavior which includes imitation.

The presence of herd behaviour often results in volatility in the stock market (Christie and Huang, 1995; Chang et al., 2000; Avramov et al., 2006) and has the tendency to drive prices away from their fundamental values (Tan et al., 2008). West 1988 points out the reason of social conformity for the presence of herding. It can also be driven by irrational sentiments and motives. The present study aims to examine an emerging economy- India, to study the presence of herd behavior. It is a comprehensive study and contributes to the body of knowledge by investigating the herd behavior in the emerging market since most of the previous studies concentrate more on the developed economies.

The concept of behavioral or cognitive biases explains the reason why most investment decisions taken by stock investors are not rational as proposed by the theory of traditional finance. The investors' judgment on the market and various stocks, and their decision to buy, sell or hold a stock is subconsciously influenced by certain cognitive biases like herding, overconfidence, conservatism, anchoring, etc. Studies state that the demographic profile of a stock investor influences these behavioral biases to a certain extent. A stock investor obtains information on various aspects of stock market and investment through various sources such as stock websites, forums, stock broking firms, newspaper, word of mouth, etc. Hence, apart from investors' demographics, the sources of financial information for their investment decisions also play a crucial role in influencing the stock investors' judgment and investment decisions that are sometimes biased and not always rational in nature.

\section{DEFINITION OF BEHAVIORAL FINANCE}

Behavioral Finance is a vast \& upcoming field which proposes that human cognition has an impact on investment decisions taken by investors in financial markets. Cognition refers the way an investor feels or thinks that results in taking biased rather than rational investment decisions in financial markets. It integrates the concepts of finance and psychology to explain the cognitive biases in investors' investment decisions.

\section{COGNITIVE BIASES}

Cognitive biases are defined as the biased behavior of investors in terms of the decisions they take during investments in the financial markets. These biased behavior constitute the behavior of herding, loss aversion, regret aversion, market information, mental accounting, price change, and price anchoring.

\section{HERDING}

Herding behavior is the most prominent and also the most influential behavioral bias in terms of making a massive impact in financial markets. Herding behavior involves a transition phase which is developed before sudden change in the trends of financial markets. Herding behavior among investors has constituted to be the reason for mass errors and creation of "bubbles" in the markets. The reason for herding behavior among investors is to secure their reputation.

\section{GENERAL TRENDS SHOWS FOLLOWING THINGS: \\ Gender}

The general idea believed is that men and women vary in the way they think and react to various aspects. Studies and experiments have been conducted to find out how male and female investors take investment decisions and react to information. Men have shown to be overconfident about their own capabilities and knowledge in relation to stock market when compared to women.

\section{Age}

Age of an individual is often equated to experience and knowledge. The general idea is that old investors have more information, experience, and expertise in stock markets and are comparatively better in making rational decisions than young investors [6]. Another idea suggests that with increase in age group they tend to be overconfident in terms of their knowledge and 
capabilities. Therefore, they are less likely to listen or follow the actions of the crowd.

\section{Annual Income}

Stock investors with higher levels of income tend to invest more in their investment avenues when compared to a stock investor with lower levels of income. A stock investor who has invested a large amount in the stock market are more likely to be risk averse and follow the actions of the crowd in order to avoid risk and secure his capital amount.

\section{Educational Qualification}

Stock investors with higher levels of educational qualification are more likely to be knowledgeable and informed about the stock market. This enables the stock investors to be overconfident about their capabilities and knowledge, which may result in not following the actions of the herd in making stock investment decisions.

\section{Marital Status}

The Spouse Effect proposes that married and unmarried individuals tend to make investment decisions and react to information differently. The investment decisions made by married stock investors may be influenced by their partners' decisions as well.

\section{Professional Services}

Most individual stock investors depend on professional services such as stock broking firms, financial experts and investment banks for obtaining financial information and knowledge regarding the stock market, which in turn affects their investment decisions. These institutions and financial experts have the advantage of being well informed and experienced [10]. They are aware of the irregularities and biases existing in the market. Therefore, it is less likely that these firms and experts are influenced by behavioral biases.

\section{Websites and Online forums}

Internet is a major source of information for any area and field. It is a platform where individuals are free to share their knowledge and opinions. Most stock investors' investment decisions are influenced by the information shared on stock market websites and online forums.

\section{Newspapers, magazines, and news channels}

Print and visual media are other major sources of information that present various aspects about the industry and the stock market. Authentic industry related and stock related news articles are published based on certain price predictive models, calculation of delta prices, etc.

\section{Word of Mouth}

Social interaction is the most common and widely dependent source of information. Most stock investors keep their ears open to obtain financial information pertaining to an industry, company or a particular stock. Based on the information obtained, they make changes in their portfolio and trading decisions. Word of mouth is a very power medium for information. 
International Journal of Trend in Scientific Research and Development (IJTSRD) ISSN: 2456-6470

Examples of stocks trended on heard behavior:

\begin{tabular}{|c|c|c|c|c|c|}
\hline S. & Company Name & Scrip Code & Data & $\begin{array}{l}\text { Time } \\
\text { Range } \\
\end{array}$ & Remarks \\
\hline 1 & $\begin{array}{l}\text { Thirani Projects } \\
\text { Ltd. }\end{array}$ & $\begin{array}{l}538464 \text { TPROJ } \\
\text { ECT Group (XT) }\end{array}$ & $\begin{array}{l}\text { High- } 53.50 \\
\text { \& Low } \\
12.50 \\
\end{array}$ & $\begin{array}{l}\text { Feb 2018- } \\
\text { May, } 2018\end{array}$ & $\begin{array}{c}\text { Just because of rumor flashed by } \\
\text { Tips providing agencies that it } \\
\text { will touch } 131\end{array}$ \\
\hline 2 & $\begin{array}{c}\text { Punjab National } \\
\text { Bank }\end{array}$ & $\begin{array}{l}532461 \text { PNB Gr } \\
\text { oup (A) }\end{array}$ & $\begin{array}{l}\text { High } 93.5 \& \\
\text { Low } 74.5\end{array}$ & $\begin{array}{l}\text { 02nd May } \\
\text { 18th May, } \\
2018\end{array}$ & $\begin{array}{l}\text { News came that NPA's are more } \\
\text { than the Net Worth of Bank. }\end{array}$ \\
\hline 3 & PC Jeweller Ltd. & $\begin{array}{l}534809 \text { PCJEW } \\
\text { ELLER Group } \\
\text { (A) }\end{array}$ & $\begin{array}{l}\text { High } 237 \& \\
\text { Low } 95.05\end{array}$ & $\begin{array}{l}\text { 27th April- } \\
\text { 2nd } \\
\text { May, } 2018\end{array}$ & $\begin{array}{c}\text { Rumors came that owners are } \\
\text { selling their stake in PC } \\
\text { Jewellers }\end{array}$ \\
\hline 4 & $\begin{array}{l}\text { Jet Airways } \\
\text { (India) Ltd }\end{array}$ & $\begin{array}{l}532617 \text { JETAIR } \\
\text { WAYS Group } \\
\text { (A) }\end{array}$ & $\begin{array}{l}\text { High } 641.95 \\
\& \text { Low } 376\end{array}$ & $\begin{array}{l}\text { 30th April- } \\
\text { 24th } \\
\text { May, } 2018\end{array}$ & $\begin{array}{l}\text { Leading to the news of increase } \\
\text { in fuel charges by government. }\end{array}$ \\
\hline 5 & $\begin{array}{l}\text { Aplaya Creations } \\
\text { Ltd. }\end{array}$ & $\begin{array}{l}511064 \text { APLAY } \\
\text { A Group }(X)\end{array}$ & $\begin{array}{l}\text { High } 5.46 \& \\
\text { Low } 2.1\end{array}$ & $\begin{array}{l}\text { 24th Jan- } \\
\text { 12th } \\
\text { March, } \\
2018\end{array}$ & $\begin{array}{l}\text { Just because of rumor flashed by } \\
\text { Tips providing agencies that it } \\
\text { will touch } 12\end{array}$ \\
\hline 6 & $\begin{array}{l}\text { Eldeco Housing } \\
\text { \&Industries Ltd }\end{array}$ & $\begin{array}{l}523329 \text { ELDEH } \\
\text { SG Group }(\mathrm{X})\end{array}$ & $\begin{array}{l}\text { High } 2180 \\
\& \\
\text { Low } 1533 \\
\end{array}$ & $\begin{array}{l}\text { 30th April- } \\
\text { 27th } \\
\text { May, } 2018\end{array}$ & $\begin{array}{l}\text { Due unhealthiness of Real State } \\
\text { sector }\end{array}$ \\
\hline
\end{tabular}

\section{CONCLUSIONS}

Herding behavior is the most common behavioral bias that impact financial markets. This study showed that stock investors are highly probable to show herding behavior when they obtain most of their financial information from word of mouth when compared to any other source of information. There exists a behavioral pattern for investors of similar demographic profile. This study showed that male investors portray less herding bias than female investors. Old stock investors portrayed more herding bias when compared to young stock investors. Marital status of the investors showed to have low impact in portraying herding bias.

Understanding the influence of the various factors explored in the study on cognitive behaviour will enable stock investors to Herding behavior is the most common behavioral bias that impact financial markets. This study showed that stock investors are highly probable to show herding behavior when they obtain most of their financial information from word of mouth when compared to any other source of information. There exists a behavioral pattern for investors of similar demographic profile. This study showed that male investors portray less herding bias than female investors. Old stock investors portrayed

more herding bias when compared to young stock

investors. Marital status of the investors showed to have low impact in portraying herding bias.

Understanding the influence of the various factors explored in the study on cognitive behaviour will enable stock investors to be more cousious and vigilant about their investment decisions and succumb herd behavior.

\section{REFERENCES}

1. Fromlet, H. (2001). Behavioral Finance-Theory and Practical Application: Systematic Analysis Of Departures From The Homo Oeconomicus Paradigm Are Essential For Realistic Financial Research And Analysis. Business economics, 6369.

2. Ritter, J. R. (2003). Behavioral finance. PacificBasin finance journal, 11(4), 429-437.

3. Kang,W. (2013). Herd behavior in financial markets. International Business Research, 6(6), 31.

4. Devenow, A., \& Welch, I. (1996). Rational herding in financial economics. European 
Economic Review, 40(3), 603-615.

5. Eagly, A. H., \& Carli, L. L. (1981). Sex of researchers and sex-typed communications as determinants of sex differences in influenceability: a meta-analysis of social influence studies. Psychological Bulletin, 90(1), 1.

6. Lin, H. W. (2011). Elucidating the influence of demographics and psychological traits on investment biases. World Academy of and Technology, Science, Engineering77, 145-150.

7. Ngoc, Luu Thi Bich. "Behavior pattern of individual investors in stock market." International Journal of Business and Management 9, no. 1 (2014): 1 .

8. Bhandari, G., \& Deaves, R. (2006). The demographics of overconfidence. The Journal of Behavioral Finance, 7(1), 5-11.

9. Sung, J., \& Hanna, S. (1998). The spouse effect on participation and investment decisions for retirement funds. Journal of Financial Counseling and Planning, 9(2), 47.

10. Bodnaruk, A., \& Simonov, A. (2015). Do financial experts make better investment decisions?. Journal of financial Intermediation, 24(4), 514-536.

11. Choi, C., Rhee, D. E., \& Oh, Y. (2014). Information and capital flows revisited: The Internet as a determinant of transactions in financial assets. Economic Modelling, 40, 191-198.

12. Shynkevich, Y., McGinnity, T. M., Coleman, S., \& Belatreche, A. (2015, December). Predicting Stock Price Movements Based on Different Categories of News Articles. In Computational Intelligence, 2015 IEEE Symposium Series on (pp. 703-710). IEEE.

13. Tauni, M. Z., Fang, H. X., \& Iqbal, A. (2017). The role of financial advice and word-of-mouth communication on the association between investor personality and stock trading behavior: Evidence from Chinese stock market. Personality and Individual Differences, 108, 55-65. 